\title{
Essay
}

\section{LINCOLN, PRESIDENTIAL POWER, AND THE RULE OF LAW}

Daniel A. Farber

\begin{abstract}
Every era has its unique challenges, but history may still offer lessons on how law empowers and restrains presidents. This Essay examines how President Lincoln negotiated the tension between crisis authority and the rule of law. This analysis requires an appreciation of the wartime imperatives, institutions, and political forces confronting Lincoln, as well as the legal framework in which he acted. Similar issues unexpectedly arose in our times in the aftermath of the $9 / 11$ attacks, providing a new point of comparison with Lincoln's era. We need to better understand how political actors and institutions, the media, and public opinion can provide support for legal norms, lest we place all of our trust in presidential self-restraint and good judgment.
\end{abstract}

AUTHOR-Sho Sato Professor of Law, University of California, Berkeley. This Essay is based on a presentation delivered on March 7, 2018 at Northwestern Pritzker School of Law as the second annual Abraham Lincoln Lecture on Constitutional Law. This Essay builds on the discussion in my 2003 book Lincoln's Constitution. In the Essay, however, I try to develop a richer understanding of the institutional context in which Lincoln operated and explore contrasts and similarities with post-9/11 antiterrorism issues. I would like to express my appreciation to Dianne Farber for her incisive editing, to Steve Calabresi for establishing this lecture series, and to him and other members of the Northwestern Law faculty for helpful comments on the lecture.

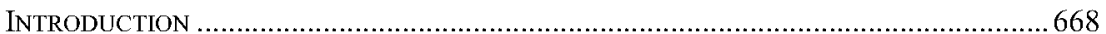

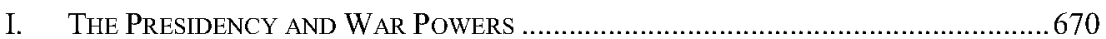

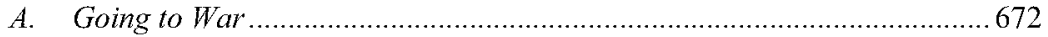

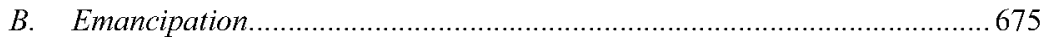

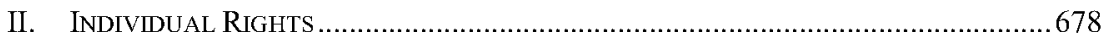

A. Military Detention and Trials in the Civil War (and the War on Terror) ...681

B. $\quad$ Free Speech in the Civil War Era (and the War on Terror) .......................692

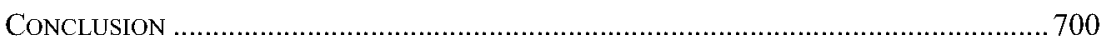




\section{INTRODUCTION}

Presidential power is most needed when normal governmental systems cannot cope with a national crisis. But that power is subject to abuse, posing a threat to the rule of law. The tensions between presidential power and the rule of law are at their highest in time of war, when presidential authority is at its peak. Never have these tensions appeared in starker form than in the Civil War, when the rule of law was put under severe pressure. President Lincoln took many extraordinary measures, such as mustering the military, suspending habeas corpus, and instituting military trials, all without the support of Congress. It is little wonder that some observers then and since have called him a dictator.

Every era has its own unique challenges, but history may still offer lessons on how law empowers and restrains presidents. This Essay addresses the constitutional dimensions of Lincoln's actions. Professor Geoffrey Stone has observed that Lincoln "melded his deep sense of the practical with his lifelong commitment to the law." 2 Understanding how Lincoln negotiated this tension requires analysis of the wartime imperatives, institutions, and political forces confronting Lincoln, as well as the legal framework in which he acted. Similar issues unexpectedly arose in our times in the aftermath of the 9/11 attacks, providing a new point of comparison with Lincoln's era.

This discussion proceeds in two parts. Part I focuses on the presidency and war powers. The issue of when the President can initiate the use of force without congressional authorization was not new in Lincoln's time and has not been fully settled even today. Lincoln's use of the war power overshadowed that of his successors. He not only went to war without even consulting Congress; he also relied on the war power to justify the Emancipation Proclamation, a presidential order overturning slavery. With a stroke of the pen, he smashed the core institution of Southern society, an institution that had support in the Constitution itself. ${ }^{3}$ However worthy the goal, one might ask, Can a President make such a fundamental legal change without the support of Congress?

Part II focuses on individual rights during the Civil War, in particular on military detention, military trials, and the use of the military to limit free

\footnotetext{
1 See Dennis J. Hutchinson, Lincoln the "Dictator," 55 S.D. L. REv. 284, 284 (2010) ("[D]ictatorship played a decisive role in the North's successful effort to maintain the Union by force of arms ... Lincoln's amazing disregard for the words of the Constitution was considered by nobody as legal." (quoting CLINTON ROSSITER, CONSTITUTIONAL DICTATORSHIP: CRISIS GOVERNMENT IN THE MODERN DEMOCRACIES 223, 226 (1948)).

${ }^{2}$ Geoffrey R. Stone, Abraham Lincoln's First Amendment, 78 N.Y.U. L. REV. 1, 28 (2003).

3 Although the Constitution refrains from using the term slavery, it refers to it in the Fugitive Slave Clause, see U.S. ConST. art. IV, $\S 2$, cl. 3, the Three-Fifths Clause, see id. art. I, $\S 2$, cl. 3, and the Article $\mathrm{V}$ provision regarding the slave trade, see id. art. $\mathrm{V}$.
} 
speech. One of Lincoln's earliest actions was to suspend the writ of habeas corpus, allowing the military to arrest and detain individuals without judicial recourse. The potential threat to liberty is obvious. Free speech did not escape unscathed during wartime, with the military arrest and trial of an outspoken Democratic opponent of the war and military closures of more than one newspaper.

Both parts of the Essay include discussion of related modern developments. Although issues relating to military trial and detention had cropped up in the World War II era, by the end of the twentieth century the subject seemed to have only historical interest. But just a year into the current century, these issues were resurrected by the "War on Terror"- the Bush Administration's response to $9 / 11 .{ }^{4}$ One of the architects of the Administration's policies observed, somewhat ruefully, that "the Bush administration's war on terrorism has kept the courts at the center of the action, sometimes intentionally, sometimes not." 5 Perhaps the most fundamental issues involved the treatment and trial of individuals detained by the government as suspected terrorists. ${ }^{6}$ The result was a prolonged confrontation between the judiciary and the President-with Congress later attempting to oust the courts from the dispute while imposing some restrictions of its own on the President, only to be thwarted in turn by the Supreme Court. ${ }^{7}$ These developments, over a century after Lincoln's death, demonstrate the contemporary significance of the issues that faced Lincoln.

Comparison with these modern events is also revealing in two other respects. The first is the way international law has shaped understanding of the parameters of war, and hence the scope of presidential authority. In Lincoln's time, as we will see, the understanding of what was then called the law of nations helped frame constitutional issues from the beginning of the

\footnotetext{
${ }^{4}$ For an excellent collection of background materials on these issues, see NORMAN ABRAMS, ANTITERRORISM AND CRIMINAL ENFORCEMENT (4th ed. 2011). I realize that the term "War on Terror" may be seen as tilting the discussion toward the military model rather than the law enforcement model. I use it here only to designate the approach to counterterrorism adopted by the Bush Administration after 9/11, without any implication that the Administration's preferred conceptual frame was correct.

5 John Yoo, FDR, Civil Liberties, and the War on Terrorism, in SECURITY V. LIBERTY: CONFLICTS Between Civil Liberties and National SeCuRity in AmeriCAN History 42, 63 (Daniel Farber ed., 2008). In contrast to Professor Yoo, Dean Erwin Chemerinsky saw the actions of the Bush Administration as an "assault on the Constitution." Erwin Chemerinsky, The Assault on the Constitution: Executive Power and the War on Terrorism, 40 U.C. DAVIS L. REV. 1, 3 (2006).

${ }^{6}$ For background on these issues, see Dawn E. Johnsen, The Story of Hamdan v. Rumsfeld: Trying Enemy Combatants by Military Commission, in PRESIDENTIAL POWER STORIES 447-85 (Christopher H. Schroeder \& Curtis A. Bradley eds., 2009).

7 The Court's decisions since $9 / 11$ have been called a departure from its previous history of deferring to the President in deciding civil liberties issues during crises involving national security. See L. A. Powe, Jr., The Role of the Court, in SECURITY V. LIBERTY, supra note 5, at 165, 181-182, 186.
} 
Civil War. Under President Bush, international law's incorporation into key domestic statutes influenced the actions of the Administration and guided the Supreme Court in its analysis of military tribunals. Arguments based on presidential war powers almost inevitably bring with them international law governing warfare.

Comparing these two eras also reveals a striking difference between how the issues were approached. The issues in Lincoln's time were framed in terms of authority, such as the authority to use military commissions or close newspapers. In the modern era, however, these questions of authority were joined by a strong concern over administrative procedures and due process. This process orientation seems distinctive to our times: in an earlier period, the constitutional alternative to executive fiat was simply the criminal process. Nineteenth-century thinkers were presumably aware that fair administrative procedures were desirable, but such procedural issues were not a factor in the debates over Lincoln's actions.

It is hard to resist the temptation to call balls and strikes, ruling certain actions constitutional or illegal. But my purpose here is not to settle the continuing constitutional dispute over the validity of Lincoln's actions (or for that matter, those of the Bush Administration). Instead, it is to understand how law has served as both a source of power and a constraint on presidential actions. In this respect, it is important to identify the areas in which Lincoln's actions were the most or the least vulnerable legally, in order to analyze how he approached this legal terrain. His efforts to navigate this terrain remain relevant to our law today, in sometimes subtle ways.

\section{THE PRESIDENCY AND WAR POWERS}

The Civil War posed a fundamental legal dilemma. The United States had a well-developed body of domestic law regulating conduct within the country, a topic also covered in depth by the Constitution. A different legal framework governs foreign affairs, including international armed conflict. Calling a conflict a "civil war" implies it is taking place within a single nation, rather than two neighboring nations that were once united. And of course, Lincoln's basis for resisting secession was its constitutional invalidity. ${ }^{8}$ All of this pointed toward a view that domestic law applied, including constitutional limits on federal power. Yet of course, the practical reality was that this was a war, with the same practical imperatives as an international conflict. International law of the time had begun to recognize a category of belligerent powers for conflicts that were not purely internal but

\footnotetext{
${ }^{8}$ Constitutional issues relating to secession are extensively discussed in Lincoln's Constitution, but will not figure in this Essay. See DANIEL FARBER, LINCOLN'S CONSTITUTION 26-114 (2003).
} 
did not involve recognized national governments. ${ }^{9}$ But this category did not map easily onto the U.S. legal framework. It was as if the legal system divided animals into two categories: fish that live in the sea and mammals that live on land - posing a difficult puzzle when a whale swims into view. ${ }^{10}$ And yet a whale cannot very well be ignored, any more than a civil war can.

Thus, from the time the Deep South seceded until the end of Reconstruction, there was a continual struggle to make issues fit into two pigeonholes - either a domestic rebellion by conspirators within states that had never left the Union, or an international war involving governments and territories that were no longer part of the constitutional order. But by its nature, a civil war fits fully within neither category. It is both a war, outside the domain of normal domestic governance, and civil, between members of what is (according to one side at least) a single political community. The result of this mismatch between legal categories and the nature of the war was a series of improvised legal arguments, invoking one category or the other as needed.

Lincoln's view was that the Civil War was both a violation of U.S. law by citizens and war with a belligerent power. " But this raised the question of which rules applied under what circumstances and in what parts of the country. For instance, when active hostilities ceased, was the South once again part of the United States or was it still held within the "grasp of war"? ${ }^{12}$

A similar classification problem was posed a century-and-a-half later by the 9/11 terrorist attack, with fierce debate over whether terrorist acts by Al Qaeda within the United States should be seen as a law enforcement

\footnotetext{
9 The British eventually recognized the South as a belligerent, but never gave the Confederacy diplomatic recognition. Allen C. Guelzo, FAteful Lightning: A New History of THE Civil WAR AND RECONSTRUCTION 284 (2012).

10 One of these key binary distinctions was between citizens and others "entitled to protection" by the government and noncitizens on foreign soil. Professor Amanda Tyler views the history as demonstrating that suspension is "the exclusive means by which the detention of persons within protection outside the criminal process for criminal or national security purposes could be brought within the law." Amanda L. Tyler, The Forgotten Core Meaning of the Suspension Clause, 125 HARV. L. REV. 901, 908-09 (2012) (emphasis added). Thus, those who are within protection (basically citizens) are subject to one set of rules, while foreign enemies are subject to another; and in the absence of suspension only the criminal process applies. But as Professor Tyler herself recognizes in her comprehensive history of habeas, civil wars are difficult to analyze within this framework, because they involve individuals who are equally describable as citizens owing allegiance and as enemies who are subjects of another government (albeit an illegitimate one). See AMANDA L. TYLER, HABEAS CORPUS IN WARTIME: From THE TOWER OF LONDON TO GUANTANAMO BAY 183-84 (2017) [hereinafter TYLER, HABEAS CORPUS IN WARTIME].

11 JOHN FABIAN WitT, LinCOLN's CODE: The LAWS OF WAR IN AMERICAN History 155-57 (2012).

12 Id. at $305-06$
} 
problem or part of the law of war..$^{13}$ As we discuss later, the Supreme Court seemingly resolved this issue in favor of the military framing, at least as a permissible approach to penalizing conduct outside of the United States.

We now turn to the Civil War experience. The story begins with the fall of Fort Sumter and the actions Lincoln took in its immediate aftermath. As we will see, the scope of presidential power was immediately at issue.

\section{A. Going to War}

The Union could hardly have been less prepared for war when Fort Sumter fell. The Army had 16,000 soldiers, mostly on the Western frontier, ${ }^{14}$ and a thousand officers. ${ }^{15}$ (For purposes of comparison, this is less than twice the size of the Chicago police force today. ${ }^{16}$ ) There was no general staff, no heavy cavalry, and little artillery. ${ }^{17}$ When Fort Sumter surrendered, Lincoln immediately issued a proclamation calling on the states to supply 75,000 militiamen and calling a special session of Congress for July $4 .{ }^{18}$ Northerners responded with enthusiasm, with the main criticism being that Lincoln should have called for more men. ${ }^{19}$ But states like Virginia in the upper South reacted to what they saw as federal coercion by seceding. ${ }^{20}$ In the meantime,

13 For a defense of the war model and an analysis of its implications, see generally Curtis A. Bradley \& Jack L. Goldsmith, Congressional Authorization and the War on Terrorism, 118 HARV. L. REV. 2047 (2005). On the difficulty of fitting the response to international terrorist organizations firmly within either the law enforcement or military models, see Rosa Ehrenreich Brooks, War Everywhere: Rights, National Security Law, and the Law of Armed Conflict in the Age of Terror, 153 U. PA. L. REV. 675, 702-23 (2004). As Professor Brooks observes, "Both international and domestic law take as a basic premise the notion that it is possible, important, and usually fairly straightforward to distinguish between war and peace, emergencies and normality, the foreign and the domestic, the external and the internal." $I d$. at 676. She argues that "these binary distinctions are no longer tenable," id. at 677 , but that they were also problematic during the Civil War, $i d$. at 702-43. In both settings, as she puts it, the erosion of these legal boundaries may be unavoidable, but it is "nonetheless genuinely cause for alarm" in terms of its impact on human rights. $I d$. at 681 . For extensive citations to the literature on this topic, see $i d$. at $685 \mathrm{nn} .23-24$.

14 James M. MCPherson, Battle Cry of Freedom: The Civil WAR ERA 271-74 (1988); KENNETH M. STAMPP, THE IMPERILED UNION: ESSAYS ON THE BACKGROUND OF THE CIVIL WAR 184 $86(1980)$.

15 WITT, supra note 11 , at 85.

${ }^{16}$ Law Enforcement Officers per Capita for Cities, Local Departments, GoverNING, http:/www.governing.com/gov-data/safety-justice/law-enforcement-police-department-employeetotals-for-cities.html [https://perma.ce/49VH-NUF6].

17 Guelzo, supra note 9, at 116.

18 Abraham Lincoln, Proclamation Calling Militia and Convening Congress (Apr. 15, 1861), reprinted in 4 THE COLLECTED WORKS OF ABRAHAM LINCOLN 331, 331-32 (Roy P. Basler ed., 1953) [hereinafter 4 COLLECTED WORKS].

19 DAVID HeRBert DONALD, LINCOLN 296 (1995). Critics ranging from Stephen Douglas to Horace Greeley called for 200,000-500,000 troops, numbers that far outstripped the North's ability to supply and manage troops at that point. 2 MiCHAEL BURLINGAME, ABRAHAM LiNCOLN: A LiFE 137-38 (2008).

${ }^{20}$ DONALD, supra note 19 , at 296-97. 
the federal government was overwhelmed trying to organize and supply this initial batch of soldiers. ${ }^{21}$

Support by Northern state governments was not merely a political asset; their active participation was essential to the war effort. If Northern governors had not supported the effort, the militia would not have been forthcoming, and the war would have ended almost as soon as it started. Moreover, state and local governments played a critical role in recruiting for the regular army by funding bounties for enlistees. ${ }^{22}$ States recruited volunteers, appointed their officers ${ }^{23}$ and sent them off in regiments bearing their state's name and the state flag. ${ }^{24}$ Not surprisingly, the Secretary of War was in constant communication with Northern governors by telegraph. ${ }^{25}$

Lincoln also summoned additional volunteers ${ }^{26}$ and paid private citizens two million dollars from government funds to help with recruiting. ${ }^{27}$ His reason for using private citizens was doubt about whether the largely Southern bureaucracy in Washington was loyal. ${ }^{28}$ These actions were of dubious constitutionality, given that Article $I$ requires that federal expenditures be supported by appropriations and vests the power to raise armies in Congress. ${ }^{29}$ In his defense of these actions, Lincoln argued that they were within the power of Congress and were taken by "a public demand" and "a public necessity" in the hope of later congressional ratification. ${ }^{30}$

In terms of later understandings of constitutional law, some of Lincoln's actions might be defended on the basis of what has been called the protective

21 Id. at 297-98; Allan NeVINS, The WAR FOR THE Union, VOluMe 1: The IMPROVISED WaR 1861-1862, at 89-91 (1959).

22 MARK E. NeEly, JR., LINCOLN AND THE DEMOCRATS: THE POLITICS OF OPPOSITION IN THE CIVIL WAR 24-39 (2017).

23 See Walter Stahr, Stanton: Lincoln's War Secretary 177 (2017) (recognizing the right of governors to commission volunteer officers).

24 GuELzo, supra note 9, at 142-43.

25 STAHR, supra note 23, at 158.

26 Abraham Lincoln, Proclamation Calling for 42,034 Volunteers (May 3, 1861), reprinted in 4 COLLECTED WORKS, supra note 18 , at 353,353-54.

27 J.G. RANDAll, CONSTITUTIONAL PROBLEMS UNDER LiNCOLN 36 n.15 (1951).

28 Phillip S. Paludan, The Presidency of Abraham LinCOln 69-71 (1994).

29 U.S. CONST., art. I, § 8 (powers to "raise and support" army and "provide and maintain" navy); id. $\S 9$ ("No Money shall be drawn from the Treasury, but in Consequence of Appropriations made by Law ...."). However, Congress ratified these actions four months later. 2 BuRLINGAME, supra note 19, at 153 ("In August, Congress, by a near-unanimous vote, approved a resolution stating that 'all the acts, proclamations and orders of the President ... respecting the army and navy of the United States ... are hereby approved in all respects legalized and made valid . . as if they had been issued and done under the previous express authority and direction of the Congress ...."').

${ }^{30}$ Abraham Lincoln, Message to Congress in Special Session (July 4, 1861), reprinted in 4 COLLECTED WORKS, supra note 18, at 421, 429. 
power of the President. ${ }^{31}$ In In re Neagle, ${ }^{32}$ for instance, the Supreme Court held that the President had inherent authority to provide security for government officers, emphasizing the inherent power of the government to protect itself and its ability to execute the laws..$^{33}$ The urgent need to protect federal facilities and the capital itself seems to fit well within this protective power, although the law had not yet clearly articulated this theory.

Of Lincoln's initial wartime actions, the only one to reach the Supreme Court in his lifetime was his declaration of a naval blockade on Southern ports. ${ }^{34}$ Ship owners protested the seizure of their ships in the absence of a declaration of war, a matter implicating not only domestic law but also international law, since it involved the rights of neutral vessels and shippers. ${ }^{35}$ In the Prize Cases, the Court upheld the blockade by a five-tofour vote. ${ }^{36}$ The Court held that the President has no power to initiate a war, but that he is obligated to respond to acts of war, whether by foreign sovereigns or rebellious states. Thus, when the rebellion broke out, the President "was bound to meet it in the shape it presented itself, without waiting for Congress to baptize it with a name; and no name given to it by him or them could change the fact. ${ }^{{ }_{37}}$ Addressing the dual nature of the Civil War, the Court said that the South qualified as a belligerent party under international law, but while this made Southerners enemies under international law, it did not absolve them of treason under domestic law. ${ }^{38}$ The dissenters argued that a state of war could not exist until Congress had passed legislation endorsing the President's actions three months after Fort Sumter; hence, ship seizures in the interim were unlawful. ${ }^{39}$ But for the majority, at least, it was clear that Lincoln had no need for congressional approval before moving to a wartime footing.

\footnotetext{
31 See Henry P. Monaghan, The Protective Power of the Presidency, 93 CoLuM. L. REv. 1 (1993).

32135 U.S. 1 (1890).

${ }^{33} I d$. at 60-61, 64-65. Also supporting the existence of presidential protective power are In re Debs, 158 U.S. 564 (1895), and United States v. Midwest Oil Co., 236 U.S. 459, 467-69, 472-74 (1915).

34 The Administration chose a blockade rather than closing Southern ports under domestic law to avoid antagonizing England and other countries. WITT, supra note 11, at 143-44.

35 For the history of the laws governing maritime war, see id. at 46-59.

3667 U.S. (2 Black) 635, 699 (1863).

37 Id. at $668-69$.

${ }^{38}$ Id. at 669-71, 674. For discussion of the belligerency concept, see Yair M. Lootsteen, The Concept of Belligerency in International Law, 166 MIL. L. REV. 109 (2000). In the Santissima Trinidad, 20 U.S. (7 Wheat.) 283 (1822), the Court had accorded belligerent rights to one side of a civil war despite lack of diplomatic recognition by the United States. Id. at 336-37.

3967 U.S. at $682,687-97$.
} 
The scope of the President's constitutional power to initiate hostilities remains unsettled even today. Section 1541(c) of the 1973 War Powers Resolution ${ }^{40}$ states a congressional view that

[t]he constitutional powers of the President as Commander-in-Chief to introduce United States Armed Forces into hostilities, or into situations where imminent involvement in hostilities is clearly indicated by the circumstances, are exercised only pursuant to (1) a declaration of war, (2) specific statutory authorization, or (3) a national emergency created by attack upon the United States, its territories or possessions, or its armed forces. ${ }^{41}$

Even under this standard, Lincoln's actions seem justified. If secession and the attack on Fort Sumter do not qualify as "a national emergency created by attack upon the United States, its territories or possessions," it is hard to imagine what could qualify. But courts today, unlike the Supreme Court in Lincoln's time, have proved unwilling to judge whether a President's use of military force is constitutional. Thus, the issue has been left to Congress and the President to negotiate.

Given that the Civil War remains the bloodiest war in American history, it is disquieting to think that Lincoln could take the nation to war unilaterally. But the point, of course, is that he did not initiate the war: the Confederacy did by attacking and capturing a U.S. military facility. It is hard to imagine that any U.S. President would let such an action pass unanswered. But of course, beyond that, the survival of the United States as a nation was at stake to a degree we have never seen otherwise since the American Revolution. Thus, whatever the exact scope of the war power, Lincoln's efforts to mobilize the country seem to fall comfortably within that scope.

\section{B. Emancipation}

At enormous human and economic cost, the Civil War established two things: the United States is a nation, not a confederation of states with a free exit option; and slavery has no place in our nation. Those, much more than the structure in Washington bearing his name or his visage on the penny, are the enduring monuments to Lincoln.

Lincoln favored emancipation in part due to his lifelong hatred of slavery, but also for pressing, pragmatic reasons. As Lincoln was aware, eliminating slavery would appeal to the public in England and France, countries whose continued neutrality was essential to the Union cause; it would strengthen the morale of the Union's black soldiers and sailors; and it

\footnotetext{
4050 U.S.C. $\S \S 1541-48(2012)$.

41 Id. $\$ 1541(\mathrm{c})$.
} 
would undermine the economic basis of Southern resistance. ${ }^{42}$ When the Union victory at Antietam dispelled concerns that emancipation would appear an act of desperation, he issued a preliminary emancipation ${ }^{43}$ and finalized it on January 1, 1863, with a declaration that "all persons held as slaves" within the Confederacy "are, and henceforward shall be free."44

This is justly Lincoln's most celebrated act. Yet it raised serious constitutional questions. It is not clear that even Congress had the power to abolish slavery - a domestic institution long under state control. ${ }^{45}$ The scope of the commerce power is very broad today, but it still is not entirely clear that the Commerce Clause would stretch so far, ${ }^{46}$ and under pre-New Deal law, the Supreme Court held that child labor was outside the scope of the Commerce Clause. ${ }^{47}$ For the President to act without congressional authorization raised even greater questions because the Constitution conspicuously vests the lawmaking power in Congress, not the Chief Executive. ${ }^{48}$

Lincoln did not claim any right to create domestic legislation. Instead, he based the Proclamation squarely on the war power. He asked, "Is therehas there ever been - any question that by the law of war, property, both of enemies and friends, may be taken when needed? And is it not needed

42 See DONALD, supra note 19, at 345; MCPHERSON, supra note 14 , at 769 .

43 Abraham Lincoln, Preliminary Emancipation Proclamation (Sept. 22, 1862), reprinted in 5 THE COLlECTED WORKS OF ABRAHAM LINCOLN 433, 434 (Roy P. Basler ed., 1953) [hereinafter 5 COLLECTED WORKS]; Abraham Lincoln, Preliminary Draft of Final Emancipation Proclamation (Dec. 30, 1862), reprinted in 6 THE COLLECTED WORKS OF ABRAHAM LINCOLN 23, 24 (Roy P. Basler ed., 1953) [hereinafter 6 COLLECTED WORKS]. On the public response to the Emancipation, see 2 BuRLINGAME, supra note 19, at 409-15. Professor Burlingame indicates that the Proclamation contributed to major Republican losses in the 1862 off-year elections. Id. at 419-23.

44 Transcript of the Proclamation, U.S. NAT'L ARCHIVES \& RECORD ADMIN. (rev. May 5, 2017), https://www.archives.gov/exhibits/featured-documents/emancipation-proclamation/transcript.html [https:/perma.ce/GF9Q-Z2L5].

45 Congress did pass a statute confiscating slaves of disloyal citizens who escaped to the Union lines or were captured by the Union, but this statute would have required individualized proof of the owners' support for the Confederacy. STAHR, supra note 23, at 223. Presumably, this statute would have been considered an adjunct to Congress's power to punish seditious acts, but it had no application to slaves whose owners were not actively supporting the Confederate cause.

46 United States v. Morrison, 529 U.S. 598 (2000), holds that Congress lacks the authority under the Commerce Clause to address domestic violence because it is noncommercial conduct and falls within an area of criminal law long controlled by the states. Id. at 617-19. It would not be hard to imagine a similar argument that restrictions on the ownership of slaves would also be outside the scope of the Commerce Clause, despite possible avenues for distinguishing the two situations.

47 Hammer v. Dagenhart, 247 U.S. 251 (1918).

48 This is the crux of Justice Hugo Black's majority opinion in Youngstown Sheet \& Tube Co.v. Sawyer, 343 U.S. 579 (1952). 
whenever taking it, helps us, or hurts the enemy?"49 His view of the war power was in line with the leading American treatise on international law, published a few years earlier, which stated that in war, a belligerent "has, strictly speaking, a right to use every means necessary to accomplish the end for which he has taken up arms." 50 Thus, "[f]rom the moment one State is at war within another, it has, on general principles, a right to seize on all the enemy's property, of whatsoever kind and wheresoever found, and to appropriate the property thus taken to its own use or to that of the captors." 51 The first of these sentences allows such seizure only when "necessary," so military necessity is the key to defining the extent of the seizure power. Well after the Civil War had ended, the Supreme Court upheld seizure of Confederate property in aid of the war effort on this basis. ${ }^{52}$

Note Lincoln's reliance on international law to demarcate the limits of military action toward civilians. Indeed, one of the enduring legacies of the Lincoln Administration was his General Order 100, also called the Lieber Code after its primary author. ${ }^{53}$ This order for the first time articulated what we now call humanitarian law, that is, the rights of civilians during wartime. As described by Professor John Witt, the Code "protects prisoners and forbids executions and assassinations," and it "announces a sharp distinction between men in arms and noncombatants." "54 Codifying the understanding of the time, the Code provided that private property could be seized only if required by military necessity. ${ }^{55}$ It entered international law as the basis of the Hague Convention of $1899 .{ }^{56}$ Articles $56-80$ protect prisoners of war

\footnotetext{
49 Abraham Lincoln, Letter to James C. Conkling (Aug. 26, 1863), reprinted in 6 COLLECTED WORKS, supra note 43 , at 406,408 .

50 HENRY WHEATON, 2 ElEMENTS OF INTERNATIONAL LAW: WITH A SKETCH OF THE History OF THE SCIENCE 75 (1st ed. 1836).

51 Id. at 80 .

52 Ford v. Surget, 97 U.S. 594, 605 (1878) (Confederate soldier could not be sued for burning cotton to prevent it from falling into Union hands; legitimate act of war); New Orleans v. The Steamship Co. 87 U.S. 387, 391 (1874) (Union seizure of dock lease valid only until occupation ended); Miller v. United States, 78 U.S. (11 Wall.) 268, 306-07 (1870) (upholding seizure of stock in a railroad company owned by a Southerner). As to whether emancipation was really necessary to the war effort, it is worth noting that President of the Confederacy Jefferson Davis was also forced to embrace this measure in the hope of recruiting black soldiers in the closing days of the war. GUELzO, supra note 9, at 369-70. Confederate General Robert E. Lee also endorsed the idea. Id. at 370-71.

53 Instructions for the Government of Armies of the United States in the Field, Prepared by Francis Lieber, Promulgated as General Orders No. 100 by President Lincoln, 24 April 1863, http:/avalon.law.yale.edu/19th_century/lieber.asp [https://perma.ce/QPR6-PDY7].

54 WITT, supra note 11 , at 2.

55 See Instructions for the Government of Armies, supra note 53, art. 38

56 WITT, supra note 11 , at 3, 342-43, 348-53.
} 
from punishment except for violation of the laws of war, the predecessor of the Geneva Convention ${ }^{57}$ that will make its appearance later in our narrative.

By making key protections subject to override in cases of military necessity, the Lieber Code exposed the conflict between the rights of noncombatants and the pressures of war, rather than fully resolving the fundamental tension between the normal rights enjoyed by individuals and the exigencies of war. ${ }^{58}$ That tension has persisted, though over time more rights have been exempted from the necessity test, as a few such as torture were originally exempted in the Code. Thus, the conflict between Lincoln's actions and the rule of law was resolved by legal rules governing wartime actions, but those rules themselves included room for military exigencies to overcome the legal requirements.

Note, however, that these rules had built-in limits. A military nexus was required, so military necessity was only relevant to actions in the theater of war or addressed at the enemy population or individuals connected with the Confederate military. Outside of those domains, the laws of war-and with them, the exception for military necessity-had no application. While military necessity could justify an order freeing slaves in the South, it could not be used to impose emancipation on border states loyal to the Union. Those slaves were not reached by the Emancipation and had to await the Thirteenth Amendment. ${ }^{59}$ Thus, the law of war both empowered Lincoln and restricted his authority.

\section{INDIVIDUAL RIGHTS}

Individual rights are often at risk in the ruthless quest for military victory. The Civil War was no exception, but it is not easy to sort out the relevant constitutional issues. Moreover, the dynamics at work may have been somewhat counterintuitive.

It may seem obvious that greater centralization creates a greater threat to liberty, making both a large federal government and a strong presidency

\footnotetext{
57 Geneva Convention (III): Relative to the Treatment of Prisoners of War, Aug. 12, 1949. On the survival of aspects of the Code into the Conventions, see WITT, supra note 11 , at 3 . On the history of developments from Order 100 to the present, see Brooks, supra note 13, at 689-90. Geneva Common Article 3 is now considered to be universally binding, even on nonsignatories. Id. at 691 .

58 WITT, supra note 11 , at 249 . Yet in doing so, the Code made military judgments of necessity subject to review by tribunals, not just part of the decision-making of a field commander. Moreover, note that at least today, military actions must be justified not only by military necessity but also must satisfy requirements of proportionality and discrimination (distinguishing between civilians and combatants). Brooks, supra note 13, at 693.

${ }^{59}$ U.S. CONST. amend. XIII, $\S 1$ ("Neither slavery nor involuntary servitude, except as a punishment for crime whereof the party shall have been duly convicted, shall exist within the United States, or any place subject to their jurisdiction.").
} 
causes for worry. There is undoubtedly truth to that view, but the Civil War experience suggests that the relationship is more complex. Weak civil institutions may be less prone to threaten liberty, but they are also less able to protect it, and in times of crisis their weakness may prompt resort to military measures.

"Small government" advocates must view the antebellum government as close to their fondest dreams. The scale of the federal government then compared with now is startling. Until four years before Lincoln took office, Congress had never appropriated any funds for a White House staff, and presidential staff typically consisted of a single secretary with one or two assistants. ${ }^{60}$ The Attorney General had only recently become a full-time government lawyer, ${ }^{61}$ and the Justice Department did not yet exist. ${ }^{62}$ The first modern regulatory agency, the Interstate Commerce Commission, was twenty-five years in the future. The FBI did not begin its work until half a century later, ${ }^{63}$ and even the Secret Service was not formed until just after Lincoln's death. ${ }^{64}$

The federal government's budget in 1860, just before Lincoln took office, was $\$ 63$ million, and the national debt was only $\$ 1.7$ million more. ${ }^{65}$ In current dollar terms, that is roughly $\$ 1.7$ billion, about half of the City of San Jose, California's 2016-2017 budget. ${ }^{66}$ Apart from postal workers, the federal government had 5837 federal employees in $1861,{ }^{67}$ about the same as

\footnotetext{
60 ShIRLey AnNe Warshaw, Guide to the White House StaFF, at ix (2013).

61 Forrest MCDOnald, The AmeriCAn Presidency: An INTEllectual History 280-83, 320 (1994).

62 STAHR, supra note 23, at 81.

63 History - Federal Bureau of Investigation, FED'N AM. SCIENTISTS (June 18, 2003), https://fas.org/irp/agency/doj/fbi/fbi_hist.htm [https://perma.cc/VPJ7-TE6C].

64 USSS History, U.S. SECRET SERV., https:/www.secretservice.gov/about/history/events [https://perma.cc/5U2J-7D5K].

65 The $19^{\text {th }}$ Century, TREASURYDIRECT (May 1, 2014) https:/www.treasurydirect.gov/govt/reports/ $\mathrm{pd} /$ histdebt/histdebt_19cent.htm [https://perma.cc/3N4N-6A6V]

66 The dollar was worth about twenty-seven times as much in 1860 as in 2017 . See Consumer Price Index (Estimate) 1800-, FED. RES. BANK OF MINN., https://www.minneapolisfed.org/community/ financial-and-economic-education/cpi-calculator-information/consumer-price-index-1800 [https:/perma.ce/WQ6T-AKK3]. So in current dollars, the 1860 federal budget translates into approximately $\$ 1.7$ billion. For the San Jose budget ( $\$ 3.2$ billion), see CITY OF SAN JOSE, 2016-2017 ADOPTED BUDGET IN BRIEF 3, http:/www.sanjoseca.gov/DocumentCenter/View/61738 [https://perma.cc/ZZ9V-RZMQ]. By the 1863 fiscal year, the War Department alone was spending $\$ 600$ million (or about $\$ 12$ billion in 2017 dollars). See STAHR, supra note 23, at 158.

${ }^{67}$ Lisa Rein, Civil War Gave Birth to Much of Modern Federal Government, WASH. PosT (Oct. 7, 2011), https://www.washingtonpost.com/politics/civil-war-gave-birth-to-much-of-modern-federalgovernment $/ 2011 / 09 / 22 / \mathrm{gIQA} 43 \mathrm{EFSL}$ _story.html?utm_term=.ed2b796e220c [https:/perma.cc/3EBA$643 Q]$.
} 
San Jose today. ${ }^{68}$ Thus, at the start of the Civil War, it was as if the San Jose city government were asked to organize a massive war effort.

For those who dream of shrinking the government until it is small enough to drown in a bathtub, ${ }^{69}$ the federal government of 1860 must have looked ready for drowning - as it did to President of the Confederacy Jefferson Davis, one imagines. ${ }^{70}$ Indeed, it is not hard to imagine that secessionists might have been deterred from taking on a federal government that had a little more heft.

Rather than protecting civil liberties during the war, the small size of the antebellum government may have had the opposite effect. In particular, the skeletal civil governance infrastructure may well have promoted greater use of the military to deal with problems. The federal government had essentially no law enforcement capacity, leaving the military in that role. When Lincoln took office, there were only about seventy federal judges in the country and a total of eighty-one federal law enforcement officials. ${ }^{71}$ (For comparison, San Jose has over ten times that number today. ${ }^{72}$ ) Similarly, the small number of federal judges in free states could not conceivably have handled all of the criminal cases arising during the war. The use of military trials in Lincoln's time might actually be seen as a result of the relative weakness of the federal government's civilian law enforcement capacity. Absent a massive expansion of the government's law enforcement apparatus, military detention and trials may have seemed the only realistic option. Whereas today, the alternative to military detention and trial would be the

68 See CITY OF SAN JOSE, supra note 66, at 3 . To put these comparisons in context, the population of the United States in 1860 was over 31 million, see 1860 Fast Facts, U.S. CENSUS BUREAU (July 18, 2017), https://www.census.gov/history/www/through_the_decades/fast_facts $/ 1860$ fast_facts.html [https:/perma.cc/VG3R-BSDL], while San Jose today has a population of just over one million, see Population, CITY OF SAN JOSE, http:/www.sanjoseca.gov/index.aspx?NID=2044 [https://perma.cc/HQ5F-533C]. Thus, the federal government had to manage a much larger population with similar resources.

69 This phrase is attributed to anti-tax advocate Grover Norquist. Bob Dreyfuss, Grover Norquist: 'Field Marshal' of the Bush Plan, THE NATION (Apr. 26, 2001), https:/www.thenation.com/article/ grover-norquist-field-marshal-bush-plan [https://perma.cc/Z4MK-VBTV].

70 As one of the factors favoring the Confederacy, which only needed to defend its own territory, Professor Burlingame notes that the North "lacked a sophisticated governmental apparatus for conducting such a huge enterprise as the Civil War; mobilizing its vast resources would pose a grave challenge to the small, creaky, antiquated bureaucratic structures then available." 2 BURLINGAME, supra note 19, at 135.

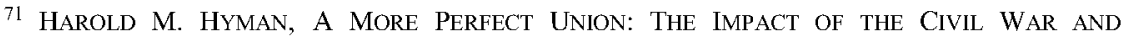
RECONSTRUCTION ON THE CONSTITUTION 96 n.37 (1973).

72 Bob Scales, Police Strategies, Police Force Analysis System: Summary Report 25 (2018), http://www.sjpd.org/CrimeStats/San_Jose_Summary_Force_Report.pdf [https:/perma.cc/BHH4-FUS3] ("As of June 2017, the San Jose Police Department had 915 sworn officers on its roster."). 
use of the FBI and federal trials, the alternative in the Civil War period might have been no federal enforcement at all.

In any event, the major civil liberties issues of the Civil War were closely connected with reliance on the military. These issues include military detention and trial (without access to the courts via habeas), and suppression of speech and press by military order. We will deal with these issues in turn.

\section{A. Military Detention and Trials in the Civil War (and the War on Terror)}

In a democracy, we do not expect to see the military sweeping up citizens and detaining them, let alone trying and convicting them for disloyalty. It was here that Lincoln's actions posed the most striking challenge to the rule of law. The primary weapons used to reconcile the two were suspension of habeas corpus, congressional ratification of presidential actions, and recourse to the laws of war as a guiding standard in the South and the theater of military operations.

\section{Habeas Suspension and Merryman}

Lincoln first suspended habeas soon after the war began, at a time when the fall of Washington seemed like a real possibility. ${ }^{73}$ There was only a skeleton military force in the city itself, and with the secession of Virginia, the only access was through Maryland. Troops seeking to reach Washington had to change trains in Baltimore, where they were attacked by mobs. Meanwhile, Maryland legislators were actively considering secession. ${ }^{74}$ Lincoln issued an order suspending habeas corpus to allow the military to restore order..$^{75}$

This order led to the arrest of a Maryland man called John Merryman, who was involved in burning railroad bridges to block troop movements. ${ }^{76}$ His lawyer filed for a writ of habeas corpus, requiring the commanding officer of the district to produce Merryman in court - an order that was duly issued by Chief Justice Roger B. Taney, ${ }^{77}$ called by one prominent historian a "pro-Southern extremist." 78 In response, one of the commander's subordinates appeared, politely refused to produce Merryman in court, and

73 He was apparently reluctant to take this step but was ultimately persuaded by Secretary of State William Henry Seward's argument that "perdition was the sure penalty for further hesitation." 2 BURLINGAME, supra note 19 , at 151.

74 STAHR, supra note 23, at 137.

75 DONALD, supra note 19, at 196-97 (1995). In considering whether suspension was really necessary, it may be relevant to note that Jefferson Davis also found it necessary to do so. GuELzo, supra note 9 , at 283 .

76 GuELzo, supra note 9, at 223.

77 Ex parte Merryman, 17 F. Cas. 144 (Taney, Circuit Justice, C.C.D. Md. 1861).

78 NEELY, supra note 22, at 145. 
asked for a continuance to consult his superiors, citing Lincoln's suspension of habeas. ${ }^{79}$ Chief Justice Taney immediately held the commanding officer in contempt. ${ }^{80}$ When the U.S. Marshal went to the fort to arrest the commanding officers, he was refused admittance, although it is not clear who made the decision or on what grounds. ${ }^{81}$ Chief Justice Taney then quickly released an opinion saying that the habeas suspension was illegal but that the courts were powerless to overcome military force. It is unclear whether Lincoln was aware of the case until after the fact, given that Chief Justice Taney raced to judgment in only two days and that telegraph lines to Washington had been cut. ${ }^{82}$ The conventional story that Lincoln directed the military to hold Merryman or other detainees regardless of court orders is plausible, but we cannot be sure of the facts. It does appear to be true, however, that General-in-Chief Winfield Scott had directed the commanding officer in Merryman's case to do so. ${ }^{83}$ Thus, Merryman posed two distinct issues: the correctness of Chief Justice Taney's view that suspension was invalid ${ }^{84}$ and the duty to obey the order even if it was incorrect.

Lincoln argued that the suspension was indeed constitutional, but also that it was compelled by necessity even if it was not. As he famously asked, "[A]re all the laws, but one, to go unexecuted, and the government itself go to pieces, lest that one be violated?" ${ }^{55}$ Lincoln's Attorney General followed up with a formal opinion defending the constitutionality of suspension. ${ }^{86}$ The Attorney General argued that it would be absurd to say that when the army captured enemy soldiers it would have to send them to the civilian courts to justify their detention. ${ }^{87}$

The strongest legal defense of Lincoln's initial suspension probably rests on the President's power to take emergency action to protect the government, rather than on a general presidential power to suspend habeas. There is also an argument, supported indirectly by later precedent, that the

79 See BRIAN MCGINTY, LINCOLN AND THE COURT 73-75 (2008).

80 See Seth Barrett Tillman, Ex Parte Merryman: Myth, History, and Scholarship, 224 MIL. L. REV. 481, 489-90 (2016). Tillman's article delves deeper into the evidence than other accounts of the Merryman case.

81 Id. at $523-24$.

82 Id. at $498-99,533$.

83 Id. at $532-33$ n. 122 .

${ }^{84}$ Ex parte Merryman, 17 F. Cas. 144, 151-52 (Taney, Circuit Justice, C.C.D. Md. 1861).

85 Abraham Lincoln, Message to Congress in Special Session (July 4, 1861), reprinted in 4 COLLECTED WORKS, supra note 18, at 421, 430 (emphasis omitted).

86 Suspension of the Privilege of the Writ of Habeas Corpus, 10 Op. Att'y Gen. 74 (1861).

87 Id. There was an extensive legal debate about this issue at the time. See NEELY, supra note 22, at $142-60$. 
Militia Act provides implicit power to detain dangerous individuals in circumstances where the civilian courts cannot enforce the law. ${ }^{88}$

The emergency argument applies only to the first months of the war, before Congress was reconvened and had the opportunity to act. ${ }^{89}$ But the scope of suspension expanded over time, until it eventually covered the entire country. The eventual arrests numbered in the thousands, with most in the South but hundreds in the North. ${ }^{90}$

Lincoln's necessity argument for suspending habeas was a fallback, suggesting some uncertainty about the legality of his action. The necessity argument itself has a bit of the flavor of a "get out of jail free" card-a dangerous card to put into the hands of the holder of such a powerful office. Note that unlike the military-necessity claim supporting emancipation, this was not an argument that his action was legal, but rather a claim that necessity required Lincoln to violate the law. We should be deeply wary of the argument that upholding the constitutional order sometimes requires violating the Constitution. Given the importance of habeas as a guarantee of individual liberty, unlawfully suspending habeas presents grave risks to democracy and the rule of law. But Lincoln did face a dire situation: not just a state of war, but an emergency threatening to shatter the country, combined with the unavailability of Congress to approve the suspension. And at the beginning, at least, the suspension was limited to the areas most at risk. ${ }^{91}$ Thus, the situation presented the strongest possible setting for invocation of this dangerous justification. Notably, this was not an argument that Lincoln was willing to deploy to support later actions such as emancipation, and since it was extralegal it did leave open the possibility that Congress or the courts might nonetheless treat the action as unlawful.

Congress eventually eliminated the constitutional issue halfway through the war with a March 1863 statute authorizing detentions at the order of the President, ratifying previous suspensions, and shielding executive officials from liability for past detentions pursuant to Lincoln's orders. ${ }^{92}$

\footnotetext{
88 For a contemporaneous holding to that effect, see In re Kemp, 16 Wis. 359 (1863).

89 Section 1 of An Act Relating to Habeas Corpus, and Regulating Judicial Proceedings in Certain Cases, ch. 81, 12 Stat. 755 (1863), provides in part:

[D] uring the present rebellion, the President of the United States, whenever, in his judgment, the public safety may require it, is authorized to suspend the privilege of the writ of habeas corpus in any case throughout the United States, or any part thereof.

90 Mark E. NeEly, JR., The Fate of Liberty: Abraham LinCOLN AND Civil Liberties 27, $123-$ 38 (1991).

91 Lincoln's argument based on necessity could have been stretched only so far. At the extreme, canceling the 1864 election might have been conducive to winning the war but would have been a body blow to the constitutional order as bad or worse than secession itself.

9212 Stat. 755. Section 4 of the statute provides:
} 
Based on a careful review of the legislative history, Professor Amanda Tyler concludes that the weight of opinion in Congress during the debates on this law was that a valid habeas suspension not only eliminates habeas as a remedy for unlawful detention, but also legalizes the detentions, eliminating the possibility of some other remedy such as a later award of damages. ${ }^{93}$ Of course, the same would not be true of a purported but invalid suspension. ${ }^{94}$

Even during the initial Maryland crisis, Lincoln acted with some restraint. Despite fears that the Maryland legislature would vote to secede, Lincoln refused to have them arrested. His reasoning was partly based on principle: the legislature had a legal right to assemble, and there was no way of knowing in advance that they would undertake any illegal action. It was also pragmatic, since he viewed any such arrests as unlikely to be effective: the legislators could be held only for a short time and would simply reassemble when released. ${ }^{95}$

Nevertheless, there can be no doubt that the power to conduct arbitrary arrests was abused. General Henry Halleck had a Missouri man arrested for saying he would not use the flag as toilet paper; a drunk in Baltimore was arrested for saying he would be the first man to hang Lincoln; and a newspaper editor in Dubuque was seized for allegedly discouraging enlistments. Lincoln intervened on occasion to reverse these decisions, but many did not get his attention. ${ }^{96}$

Merryman was not only the occasion for a judicial ruling on the President's suspension power but also raised a separate critical issue: the extent of the Executive Branch's duty to obey court orders. Although the issue of the validity of Lincoln's initial habeas suspension ultimately became moot, it remains true that the military failed to obey a court order to produce Merryman in court. There is some argument that, if valid, the suspension

[A]ny order of the President, or under his authority, made at any time during the existence of the present rebellion, shall be a defence in all courts to any action or prosecution, eivil or criminal, pending, or to be commenced, for any search, seizure, arrest, or imprisonment, made, done, or committed, or acts omitted to be done, under and by virtue of such order, or under color of any law of Congress...

$\S 4,12$ Stat. at 756 . Note that this order provides a defense for actions that are actually authorized by a presidential order, but not for actions "under color" of the order-that is, actions that were purportedly but incorrectly based on the order.

93 See Amanda L. Tyler, Suspension as an Emergency Power, 118 YALE L.J. 600, 639-51 (2009).

94 Merryman did sue the commanding officer for false arrest but was unsuccessful. Tillman, supra note 80 , at 494 .

95 Abraham Lincoln, Executive Order (Apr. 25, 1861), reprinted in John T. Woolley \& Gerhard Peters, Abraham Lincoln, THE AM. PRESIDENCY PROJECT, http://www.presidency.ucsb.edu/ws/ index.php?pid=70145 [https://perma.cc/ZKP4-EY5Q].

96 See NEELY, supra note 90, at 54-68. 
eliminated any duty to obey that order. ${ }^{97}$ But if Chief Justice Taney did have jurisdiction despite the suspension, Merryman raises very troubling issues. Obedience to judgments in specific cases cuts close to our conception of the rule of law, and failing to do so could be justified only in the face of the direst necessity. If Chief Justice Taney or other judges had begun freeing prisoners in Maryland on a large scale, the effort to save Washington might have collapsed. The case for extralegal action seems somewhat stronger due to Chief Justice Taney's refusal to allow the government time to respond more fully and lingering uncertainty about whether his order would have been appealable to the full Supreme Court. ${ }^{98}$ And it is hard to imagine what Chief Justice Taney was thinking in sending the U.S. Marshal to dragoon into his courtroom a commander in a field of active military operations. Still, the necessity argument is dangerous ground given the nature of the threat to the rule of law, though it is not easy to think of times when the peril was more desperate than the threat to Washington at the time.

Fortunately, the question of whether or when the President can disobey a court order has not been tested since Merryman, if indeed it was actually involved even in Merryman. But the availability of the courts to determine the legality of detention did emerge again at the beginning of the current century, when habeas became central to judicial oversight of the government's treatment of detainees in the War on Terror. ${ }^{99}$ In Hamdi $v$. Rumsfeld, the Court held that Congress's authorization to use force against Al Qaeda and its allies authorized the President to detain without trial suspected "illegal combatants," provided that the military provided them some kind of hearing in which to contest their inclusion in this category. ${ }^{100}$ At least as to citizens, this ruling is somewhat hard to square with much of the history of habeas, given that there had been no claim that the writ had been suspended. ${ }^{101}$

In response to judicial decisions seen as unduly favorable to suspected members of the Taliban and Al Qaeda, Congress attempted to curtail judicial

97 An alternative argument is that, if the suspension was valid, Chief Justice Taney had no power to hear the case after learning that the detention was at the order of the President. On this view, suspension of habeas is akin to a lack of subject matter jurisdiction, which eliminates the power of the court to enter binding orders. See DAvid L. SHAPIRO, Civil Procedure: PreClusion IN CIVIL ACtions 25 (2001) (explaining the traditional rule).

98 See Tillman, supra note 80 , at 505-07.

99 For detailed analyses of the role of habeas and its limits in post-9/11 detentions, see TYLER, HABEAS CORPUS IN WARTIME, supra note 10, at 246-76, and Richard H. Fallon, Jr. \& Daniel J. Meltzer, Habeas Corpus Jurisdiction, Substantive Rights, and the War on Terror, 120 HARV. L. REV. 2029 (2007). As Professors Fallon and Meltzer note, the criminal enforcement model has generally served as the baseline in detention cases. See Fallon \& Meltzer, supra at 2067.

100542 U.S. 507, 509 (2004).

101 See TYLER, HABEAS CORPUS IN WARTIME, supra note 10, at 260-62, 276. 
review of military trials of terrorists. The Military Commissions Act of $2006^{102}$ modified the rules governing detainees while also addressing judicial review. The most fundamental change made by the statute was to replace the writ of habeas corpus with more limited remedies in the case of "an alien detained by the United States who has been determined by the United States to have been properly detained as an enemy combatant or is awaiting such determination." 103

The Supreme Court struck down the anti-habeas provision of the Military Commissions Act in Boumediene v. Bush. ${ }^{104}$ In an opinion by Justice Kennedy, the Court held that the United States' de facto sovereignty over the Guantanamo Base was sufficient to bring it within the scope of the constitutional guarantee of habeas, and that the statute was therefore a violation of the Suspension Clause of the Constitution. ${ }^{105}$ In a vehement dissent, Justice Scalia angrily predicted that the Court's decision would "almost certainly cause more Americans to be killed" 106 and that the "Nation will live to regret what the Court has done today."107

Justice Kennedy's majority opinion, however, emphasized that the historic roots of habeas remain relevant, ${ }^{108}$ and that liberty remains a key

102 Pub. L. No. $109-366,120$ Stat. 2600

$103 \S 7$ (a), 120 Stat. at 2636 . The term "enemy combatant" was broadly defined to include anyone "who has engaged in hostilities or who has purposefully and materially supported hostilities against the United States." $§ 3(a)(1), 120$ Stat. at 2601. Moreover, the provision appeared to apply even to permanent residents in the United States. Id. The statute also attempted to oust the courts from independently interpreting the Geneva Conventions. $\S 6(\mathrm{a})(3), 120$ Stat. at 2632. Notably, however, Congress did not contest the Court's determination that the Geneva Conventions do apply to the detainees. $\S 3,120$ Stat. at 2625 .

104 See 553 U.S. 723 (2008). In an earlier decision, Rasul v. Bush, 542 U.S. 466 (2004), the Court had held that the writ extended to the Guantanamo Base under the habeas statute. Justice John Paul Stevens's opinion for the Court distinguished statutory jurisdiction from the question of whether the Constitution itself required access to the writ by detainees there. The Military Commissions Act eliminated this statutory ground, forcing the Court to confront the constitutional issue in Boumediene. Nevertheless, Rasul prefigured the result in Boumediene. Although Rasul was based on statutory grounds, "no one who reads the Court's opinion in Rasul could seriously doubt that the jurisdictional question must be answered the same way in purely constitutional cases, given the Court's reliance on the historical background of habeas generally in answering the statutory question." 553 U.S. at 799 (Souter, J., concurring). For extensive discussion of Boumediene, its background, and its implications, see generally Baher Azmy, Executive Detention, Boumediene, and the New Common Law of Habeas, 95 IOWA L. REV. 445 (2010). In Professor Azmy's view, the ruling "reject[ed] for the first time in history the collaborative judgment of the political branches exercised in connection with military operations." $I d$. at 448

105 Boumediene, 553 U.S. at 797-98 (opinion of the Court).

106 Id. at 828 (Scalia, J., dissenting).

$107 \mathrm{Id}$. at 850 .

108 Justice Kennedy acknowledged that "[o]fficials charged with daily operational responsibility for our security may consider a judicial discourse on the history of the [English] Habeas Corpus Act of 1679 and like matters to be far removed from the Nation's present, urgent concerns." Id. at 797 (opinion of the 
value even in the face of dangerous threats to national security. A strong national security apparatus is a necessity, he wrote, but

[s]ecurity subsists, too, in fidelity to freedom's first principles. Chief among these are freedom from arbitrary and unlawful restraint and the personal liberty that is secured by adherence to the separation of powers. It is from these principles that the judicial authority to consider petitions for habeas corpus relief derives. ${ }^{109}$

Habeas did not operate as an effective check on executive power during the Civil War due to suspension of the writ. But until Congress acted in 1863 to provide immunity, Lincoln and his subordinates faced a very real legal threat of a different kind. As Professor James Pfander has shown, in the nineteenth century, the key safeguard for the rule of law was the potential for common law tort actions against individuals. ${ }^{10}$ The law provided remedies for unlawful government action in the form of trespass actions for damages for wrongful confinement and for destruction and taking of property. ${ }^{11}$ By giving certificates for requisitioned property, the government was thought to create an enforceable contract. ${ }^{112}$ For instance, in a case from the Mexican-American War, the Supreme Court awarded damages for the military's requisition of a private contractor's property on foreign soil. ${ }^{113}$ The defendant's good faith in seizing property was not a defense to a damages suit, ${ }^{114}$ though if an action was justified by military necessity the financial burden was ultimately transferred from the officer to the government. ${ }^{115}$ Officers were also personally liable for unlawful detention. ${ }^{116}$ Thus, even in the absence of habeas, unlawful actions by the military still operated in the shadow of potential liability.

In contrast, as Professor Pfander explains, such damage remedies have not been available to individuals unlawfully detained as part of the War on Terror. ${ }^{17}$ Rather, "the victims of extraordinary renditions, prolonged

Court). He continued, "[e]stablished legal doctrine, however, ... must be consulted for its teaching.

Remote in time it may be; irrelevant to the present it is not." Id.

$109 \mathrm{Id}$.

110 See James E. Pfander, Dicey's Nightmare: An Essay on the Rule of Law, CALIF. L. REV. (manuscript at 2,8) (on file with Northwestern University Law Review) (leading nineteenth-century English thinker relied on common law remedies such as trespass actions to ensure government accountability).

111 Id. at 4-5.

112 Id. at 25.

113 Mitchell v. Harmony, 54 U.S. (13 How.) 115 (1851).

114 Little v. Barreme, 6 U.S. (2 Cranch) 170, 177-79 (1804).

115 United States v. Russell, 80 U.S. 623, 628-30 (1871).

116 Pfander, supra note 110, at 18-19.

117 Id. at 21-24. 
detention, and enhanced interrogation have consistently lost their suits for compensation in the federal court system on one basis or another." 118 For instance, the D.C. Circuit rejected a suit by a translator who had been detained for nine months, placed in solitary confinement, and physically abused before finally being released without charges. ${ }^{119}$ The court held that there was no federal cause of action. ${ }^{120}$ Just last year, the Supreme Court held that no remedy was available for victims of a post-9/11 sweep of immigrants in the United States, even if the sweep was based on constitutionally impermissible grounds and involved unconstitutional mistreatment of detainees. ${ }^{121}$

To return the focus to the Civil War era, it is hard to imagine a nineteenth-century court agreeing. If Congress had not later provided immunity and Lincoln's orders had been found invalid, both he and his subordinates might have faced tort liability, particularly if Congress declined to indemnify them. Thus, in some respects, the rule of law was stronger in the Civil War era than today.

\section{Military Trials}

During the Civil War, military detention could end in release but could also lead to trials before military tribunals rather than civil courts. The most easily defended use of military trials was within areas of active military operations, under immediate threat of invasion, or under military occupation. Imposition of martial law in those areas does not seem to have been controversial. ${ }^{122}$ Similarly, martial law was often imposed in areas of active guerilla operations, such as much of Missouri. ${ }^{123}$ And in occupied territory, the military rule was necessary to ensure that the area remained subdued. ${ }^{24}$

\footnotetext{
118 JAMEs E. PfAnder, CONSTITUTIONAL TORTS AND THE WAR ON TERROR, at xv (2017).

119 Doe v. Rumsfeld, 683 F.3d 390, 396 (D.C. Cir. 2012).

${ }^{120} \mathrm{Id}$. at 394 . The court gave these justifications for dismissal:
}

Doe's allegations against Secretary Rumsfeld implicate the military chain of command and the discretion Secretary Rumsfeld and other top officials gave to [Navy Criminal Investigative Service] agents to detain and question potential enemy combatants. . . Litigation of Doe's case would require testimony from top military officials as well as forces on the ground, which would detract focus, resources, and personnel from the mission in Iraq. And . . . allowing such an action would hinder our troops from acting decisively in our nation's interest for fear of judicial review of every detention and interrogation.

Id. at 396.
121 Ziglar v. Abbasi, 137 S. Ct. 1843, 1848 (2017).
122 J. G. RANDALL, CONSTITUTIONAL PROBlems Under LinCOLN 171 (rev. ed. 1951).
123 Id.; NEELY, supra note 22, at 32-48.
124 MCPHERSON, supra note 14, at 352; PALUDAN, supra note 28, at 234-35. 
The law was clear about the validity of martial law under these circumstances. Over a decade before the War, in Luther v. Borden, ${ }^{125}$ a case better remembered for its holding on the political question doctrine, the Supreme Court also upheld the imposition of martial law to deal with an armed insurrection in Rhode Island (of all places). Chief Justice Taney's opinion for the Court found it unquestionable that a government can use military power in case of an insurrection too strong to be controlled by civilian authorities. ${ }^{126}$ This rule was strongly reaffirmed in a later opinion by Justice Oliver Wendell Holmes, Jr. ${ }^{127}$ In occupied territory, the validity of military rule was also clear under international law. As the Supreme Court held well after the end of the war, the law applicable in occupied territory is not the peacetime legal system. ${ }^{128}$ After asking rhetorically what law applies in invaded territory, the Court answered,

[I]t is military law, - the law of war,- and its supremacy for the protection of the officers and soldiers of the army, when in service in the field in the enemy's country, is as essential to the efficiency of the army as the supremacy of the civil law at home, and, in time of peace, is essential to the preservation of liberty. ${ }^{129}$

But the use of military tribunals in areas of the North remote from the fighting is harder to justify. ${ }^{130}$ These trials were authorized by Secretary of

12548 U.S. (7 How.) 1 (1849).

126 Id. at $41-46$.

127 Moyer v. Peabody, 212 U.S. 78, 84-85 (1909).

128 Dow v. Johnson, 100 U.S. 158 (1879).

129 Id. at 170; see also Coleman v. Tennessee, 97 U.S. 509, 517 (1879) (right to govern territory of enemy is incident of war). Professor Witt traces the application of military law to civilians and the use of military commissions to try violations of the laws of war "by or upon" the U.S. military to General Scott's campaign in the Mexican-American War. WITT, supra note 11, at 123.

130 Professor Martin Lederman mounts a spirited attack on the constitutionality of wartime military tribunals in Martin S. Lederman, Of Spies, Saboteurs, and Enemy Accomplices: History's Lessons for the Constitutionality of Wartime Military Tribunals, 105 GEO. L.J. 1529 (2017). I take it, however, that the argument is meant to apply only to trials in areas where legitimate civil authorities are still functioning and able to maintain order, which is to say not within the active theater of war or in occupied but not yet subdued territory. For instance, Professor Lederman justifies one set of military trials during the Revolutionary War as follows:

[I]n late 1777, Congress authorized courts-martial to convene trials around Philadelphia for a limited period, because the British occupation of that city had rendered the civil courts there incapable of dealing with the problem - an instance of genuine necessity, which is also consistent with modern constitutional doctrine, but which does not provide a justification for military trials of offenders in our current armed conflicts, all of whom could easily, indeed, more efficiently, be tried in Article III courts.

Id. at 1676. It is also unclear whether he believes the military commissions are appropriate for acts committed in violation of the laws of war, such as wanton killing of civilians. Professor Lederman argues that spying is not a violation of the laws of war, see $i d$. at $1600-04$, leaving unclear what his position would be on conduct that actually does violate the laws of war. Professor Lederman finds it puzzling that 
War Edwin Stanton in the summer of $1862,{ }^{131}$ and the procedures were supervised by the advocate general. At the beginning, most arrests were initiated by state or local officials, but after a month, further requests required approval from Washington, a military commander, or the governor. ${ }^{132}$ The most defensible category of trials involved illegal combatants - military or military support personnel not in uniform. ${ }^{133}$ When the issue reached the Supreme Court after the war in Ex parte Milligan, ${ }^{134}$ the Court ruled that military trials were impermissible in areas outside the war zone, except for individuals connected with the U.S. military, where "the courts are open, and in the proper and unobstructed exercise of their jurisdiction." 135

An 1863 statute provided immunity for "any order of the president, or under his authority, made at any time during the existence of the present rebellion ... for any search, seizure, arrest, or imprisonment." ${ }^{136}$ In 1866 , the statute was strengthened by expanding immunity to actions taken under color of Lincoln's orders but not actually in compliance with the orders. ${ }^{137}$ These grants of immunity were upheld after the War was over by the Supreme

covert action by non-uniformed soldiers is considered a violation of the laws of war, see id. at 1602-03, $1602 \mathrm{n} .369$, but the answer would seem to be that hostile acts by non-uniformed soldiers undermine the protection that the laws of war seek to give to nonmilitary personnel.

131 Secretary Stanton's order called for arrest and trial of anyone "who may be engaged, by act, speech, or writing, in discouraging volunteer enlistments, or in any way giving aid and comfort to the enemy, or in any other disloyal practice against the United States." STAHR, supra note 23, at 232. Lincoln later ratified Secretary Stanton's order in a proclamation of his own. Id. at 247.

132 STAHR, supra note 23 , at 234

133 On trials for violation of the laws of war, see In re Yamashita, 327 U.S. 1 (1946), and Ex parte Quirin, 317 U.S. 1 (1942).

13472 U.S. (4 Wall.) 2 (1866).

135 Id. at 127.

136 An Act Relating to Habeas Corpus, and Regulating Judicial Proceedings in Certain Cases, ch. 81, $\S 4,12$ Stat. 755 (1863). Section 4 provides:

[A]ny order of the President, or under his authority, made at any time during the existence of the present rebellion, shall be a defence in all courts to any action or prosecution, civil or criminal, pending, or to be commenced, for any search, seizure, arrest, or imprisonment, made, done, or committed, or acts omitted to be done, under and by virtue of such order, or under color of any law of Congress, and such defence may be made by special plea, or under the general issue.

Id. $\S 4$. Section 5 provides for removal of any suits to federal court, see id. $\S 5$; Section 6 allows Supreme Court review, see id. $\S 6$; and Section 7 provides a two-year statute of limitations, see id. $\S 7$. Sections 5 through 7 include not only acts pursuant to presidential order, but also acts "under color" of such an order (hence possibly not actually authorized by the order). See id. $\S \S 5-7$.

137 An Act to Amend an Act entitled "An Act relating to Habeas Corpus, and regulating Judicial Proceedings in certain Cases," approved March third, eighteen hundred and sixty-three, ch. 80, 14 Stat. 46 (1866). The statute provides immunity for "any search, seizure, arrest, or imprisonment made, or any acts done or omitted to be done during the said rebellion, by any officer or person, under and by virtue of any order, written or verbal, general or special, issued by the President or Secretary of War, or by any military officer." $I d$. 
Court in Mitchell v. Clark. ${ }^{138}$ The Court explained that officials had been forced to take extralegal action with regard to individuals at the beginning of the War, often in forms that would have been valid with congressional authorization. "In a few cases," however, there were "acts performed in haste and in the presence of an overpowering emergency" for which "there was no constitutional power anywhere to make them good." 139 The Court found "no reasonable doubt" about the validity of this law. ${ }^{140}$

Lincoln himself seems to have regarded some actions as extralegal, required by his oath of office even if technically illegal, and undertaken in the hope that they would be ratified by Congress. ${ }^{141}$ Taking action in the hope of later ratification was not without precedent, such as President Thomas Jefferson's justification for undertaking the Louisiana Purchase without (as he saw it) legal warrant. ${ }^{142}$

It is again enlightening to move forward in time so we can contrast the Civil War era with more recent events. The use of military tribunals became an issue 150 years after the Civil War in Hamdan v. Rumsfeld,$^{143}$ another case from the War on Terror. Justice John Paul Stevens led the Court in overturning the Administration's efforts to evade legal restrictions. Hamdan involved the use of military commissions to try enemy belligerents under the presidential order discussed earlier. In an opinion by Justice Stevens, the Court held that the President lacked the power to establish military tribunals under congressional enactments and under the Geneva Conventions. ${ }^{144}$ Specifically, the Court held that the military commission convened to try Hamdan, allegedly Osama bin Laden's driver and bodyguard, lacked the power to proceed because its structure and procedures both violated the Geneva Conventions. ${ }^{145}$

After reviewing the history and authority for military commissions, Justice Stevens concluded that the President had the authority to convene

138110 U.S. 633,640 (1884).

139 Id.

${ }^{140} \mathrm{Id}$.

141 Abraham Lincoln, Message to Congress in Special Session (July 4, 1861), reprinted in 4 COLLECTED WORKS, supra note 18 , at $421,428-30$.

142 Letter from Thomas Jefferson to John C. Breckinridge (Aug. 12, 1803), reprinted in THOMAS JEFFERSON, WRITINGS 1138-39 (1984).

143548 U.S. 557 (2006).

144 For a detailed discussion of the Court's use of the Geneva Conventions, see Oona A. Hathaway, Hamdan v. Rumsfeld: Domestic Enforcement of International Law, in INTERNATIONAL LAW STORIES 229 (John E. Noyes, Laura A. Dickinson \& Mark W. Janis eds., 2007).

${ }^{145}$ Hamdan, 548 U.S. at 567. For commentary on the case, see Erwin Chemerinsky, The Assault on the Constitution: Executive Power and the War on Terrorism, 40 U.C. DAVIS L. REV. 1, 13-15 (2006), and Stephen I. Vladeck, Congress, the Commander-in-Chief, and the Separation of Powers After Hamdan, 16 TRANSNAT'L L. \& CONTEMP. PROBS. 933, 964 (2007). 
such commissions, but only in circumstances justified by the law of war, and that such commissions are bound by the common law of war. ${ }^{146}$ In Part V of his opinion (joined only by Justices Souter, Ginsberg, and Breyer), Justice Stevens examined the traditional types of military commissions convened historically, concluding that Hamdan's tribunal was a "law-of-war commission" convened typically on the battlefield and with jurisdiction limited to offenses in violation of the laws of war. ${ }^{147}$ Justice Stevens reasoned that because the charging document alleged a conspiracy beginning long before September 11,2001, and included no overt acts that actually violated the laws of war, the military commission was unlawful and not the source of military necessity. ${ }^{148}$ Speaking for a majority, Justice Stevens also reasoned that regardless of whether Hamdan had been charged with an offense cognizable by military commission, the commission did not have the authority to proceed because its procedures were illegal. ${ }^{149}$ Summarizing the Court's holding, Justice Stevens concluded with a statement that "in undertaking to try Hamdan and subject him to criminal punishment, the Executive is bound to comply with the rule of law that prevails in this jurisdiction."'150

\section{B. Free Speech in the Civil War Era (and the War on Terror)}

In some situations, military authority was brought to bear on antiwar advocates, raising serious issues about freedom of speech. We begin with the most notorious case involving prosecution of a prominent antiwar politician and then consider military closures of newspapers.

\section{The Vallandigham Case}

The Vallandigham case exemplified one of Lincoln's ongoing problems: his limited ability to control the actions of generals and other subordinates. Lincoln was sometimes able to correct missteps by generals, such as General Ulysses S. Grant's order expelling all Jews from the area

\footnotetext{
146 Hamdan, 548 U.S. at 593-95.

147 Id. at $595-97$.

148 Id. at 600-13. Here Justice Stevens included a lengthy argument based on historical sources, precedent, and international law for why the conspiracy with which Hamdan was charged was not a war crime.

149 Id. at 613 . Justice Stevens found first that the procedures violate the Uniform Code of Military Justice (UCMJ) because they are a departure from traditional court martial procedures unjustified by military exigency. $I d$. at 625 . In a section only commanding a plurality-Part VI.D.iv-Justice Stevens also found that a provision of the Geneva Conventions applied to Hamdan, and that the procedures of the military commission did not meet its requirements. $I d$. at 633-35.

${ }^{150} \mathrm{Id}$. at 635.
} 
under his command. But sometimes, as in the Vallandigham case, he felt compelled to back up actions with which he disagreed. ${ }^{151}$

In the spring of 1863, antiwar sentiment was growing, fed by a series of Confederate victories and controversy (up to and including riots) over the newly created military draft. ${ }^{152}$ Clement Vallandigham was an Ohio politician who had just been voted out of Congress ${ }^{153}$ and was anxious to restart his career, which he attempted to do with a series of inflammatory speeches attacking the war and in particular emancipation as a war aim. ${ }^{154}$ This flew in the face of an order by General Ambrose Burnside banning expressions of sympathy with the enemy and express or implied treason. ${ }^{155}$

General Burnside was an incompetent commander who had been moved to Ohio after his troops were slaughtered at the Battle of Fredericksburg. Appalled by Vallandigham's attacks on the war, he declared martial law and issued an order that the "habit of declaring sympathies for the enemy will not be allowed in this Department." ${ }^{156}$ General Burnside had Vallandigham arrested in the middle of the night and tried by a military tribunal for expressing "sympathy for those in arms against the government of the United States" and "declaring disloyal sentiments and opinions with the object and purpose of weakening the power of the government." ${ }^{57}$ When Vallandigham sought habeas, the judge declined because of the risk posed by "[a]rtful men, disguising their latent treason" and spreading "pestilent heresies among the masses of the people." 158 Vallandigham's strategy was successful, however, in prompting his nomination as the Democratic candidate for governor. ${ }^{159}$

151 DEAN SPRAGUE, FREEDOM UNDER LINCOLN 303 (1961). For a discussion of Lincoln's role as an arbitrator between contesting cabinet officers, see $i d$. at 157-58.

152 Stone, supra note 2, at 3-4.

$153 \mathrm{Id}$. at 7 . Professor Stone attributes this to successful gerrymandering by the Republicans. $I d$.

$154 I d$. at $8-9$.

155 Michael Kent Curtis, Lincoln, Vallandigham, and Anti-War Speech in the Civil War, 7 WM. \& MARY BILL OF RIGHTS J. 105, 107, 112-24, 131-33 (1998). Further details about the case can be found in Vallandigham's biography, FRANK L. KLEMENT, THE LIMITS OF DISSENT: ClEMENT L. VALLANDIGHAM AND THE CIVIL WAR 149-89 (1970). Vallandigham was a former friend of Secretary of War Stanton, himself a former Democrat. STAHR, supra note 23, at 267

156 Stone, supra note 2, at 5 (quoting General Order No. 38 (Apr. 13, 1863), in THE TRIAL OF HON. Clement L. Vallandigham by a Military COMmission 7, 7 (Cincinnati, Rickey \& Carroll 1863)).

${ }^{157}$ Id. at 10 (quoting Ex parte Vallandigham, 28 F. Cas. 874, 875 (C.C.D. Ohio 1863)). General Burnside said the public was free to vote the government out and "freely discuss the policy in a proper tone" rather than "license and intemperate discussion." Id. (quoting Vallandigham, 28 F. Cas. at 877).

158 Vallandigham, 28 F. Cas. at 923 . The Supreme Court dismissed the case for jurisdictional reasons. See Ex parte Vallandigham, 68 U.S. (1 Wall.) 243, 251-53 (1863).

159 Stone, supra note 2, at 12. 
Lincoln was also under some pressure not only from Democrats, who viewed Vallandigham as a free-speech martyr, ${ }^{160}$ but also from supporters of his own party. Two prominent newspapers denounced Vallandigham's conviction for criminalizing the mere expression of opinion. ${ }^{161}$ Senator Lyman Trumbull from Illinois, a moderate Republican, said that the goal of the war was to protect liberty, not suppress it. ${ }^{162}$ Lincoln's Cabinet considered General Burnside's action a mistake but concluded that it would not be prudent to overrule the General. ${ }^{163}$ Lincoln stood by General Burnside, but commuted Vallandigham's sentence to banishment to the Confederacy. ${ }^{164}$ Democratic newspapers harshly criticized the arrest, and at least some of the Republican press was also hostile, calling it a great mistake and a blow to freedom. ${ }^{165}$

Lincoln defended his support for General Burnside, in a now-famous open letter, on the grounds that Vallandigham was not simply criticizing the Administration but "laboring, with some effect," to interfere with military recruiting and the draft. ${ }^{166}$ In the most famous line of the letter, Lincoln asked, "Must I shoot a simple-minded soldier boy who deserts, while I must not touch a hair of a wiley agitator who induces him to desert?"167 Since Lincoln was regularly confronted with requests that he pardon young soldiers who had attempted to desert (and not infrequently did so), this must have seemed a rather poignant dilemma to him. Nevertheless, the arrest of Vallandigham was clearly a political mistake, making him a martyr for free speech. ${ }^{168}$

In its first significant opinions on the First Amendment, which came in the World War I era (fifty years after Lincoln's death), the Court was willing to uphold speech that merely had a "natural tendency" toward interfering with the war effort. ${ }^{169}$ By that test, Vallandigham's conviction was undoubtedly valid because his speech had a clear potential for reducing military recruitment. Under today's understanding of the First Amendment,

160 Guelzo, supra note 9, at 182-83.

161 Stone, supra note 2, at 13.

$162 \mathrm{Id}$. at 14

$163 \mathrm{Id}$. at 16

164 Id. at $16-17$.

165 Id. at $17-18$

166 Abraham Lincoln, Letter to Erastus Corning and Others (June 12, 1863), in 6 COLLECTED WORKS, supra note 43, at 260, 266. For an analysis of the letter, see Stone, supra note 2, at 21-27.

167 Abraham Lincoln, Letter to Erastus Corning and Others, supra note 166, at 266.

168 NEELY, supra note 22, at 90-92.

169 Abrams v. United States, 250 U.S. 616 (1919); Debs v. United States, 249 U.S. 211, 216 (1919) (upholding the conviction of a third-party presidential candidate for criticizing the war and thereby hindering recruiting); Schenck v. United States, 249 U.S. 47 (1919). 
however, punishing Vallandigham's speech was almost certainly unconstitutional. Under current law, speech advocating illegal conduct is constitutionally protected unless it is directed to producing imminent lawless action and is likely to do so. ${ }^{170}$ Vallandigham's intent to interfere with the military was unclear, and there was no evidence that he was likely to succeed if he did have that intention. But the case establishing the modern rule was decided over a century after Lincoln's death.

There is little reason to think that a court in the 1860 s would have thought Vallandigham's speech was protected by the First Amendment in wartime. In that sense, Lincoln's position could be considered consistent with the rule of law. But even at the time, it was clear that cases like Vallandigham threatened freedom of speech. Fortunately, there were relatively few cases of private individuals arrested in the North for expressing dissent. ${ }^{171}$

\section{Newspaper Closures}

On several occasions, the military shut down newspapers, at least temporarily. ${ }^{172}$ The New York World was shut down after it fell for what today we might call fake news. ${ }^{173}$ Seeking to drive up the price of gold and make a killing on the market, a journalist forged an Associated Press story that the President was calling to draft 400,000 men as an act of desperation. ${ }^{174}$ Lincoln ordered the arrest of the editors and seizure of the paper's offices, fearing that this was a Confederate plot, though the order was later countermanded. ${ }^{175}$

General Burnside apparently had not learned his lesson after the Vallandigham incident, since he went after an annoying newspaper soon thereafter. ${ }^{176}$ The Chicago Times was another of his bêtes noires. The Times had denounced the Emancipation Proclamation as a "monstrous usurpation," said the government was sacrificing soldiers' lives without cause, and spouted racist rhetoric. ${ }^{177}$ After the Times published a fake letter, purporting

${ }^{170}$ Brandenburg v. Ohio, 395 U.S. 444 (1969).

171 Paul Finkelman, Civil Liberties and Civil War: The Great Emancipator as Civil Libertarian, 91 MICH. L. REV. 1353, 1374 (1993) ("[T] he small number of such arrests do not constitute the stuff of a reign of terror or an imposition of tyranny ....").

172 There was a flurry of actions against Confederacy-friendly newspapers in the early days of the Civil War, particularly in contested border states. HAROLD HOLZER, LINCOLN AND THE POWER OF THE PRESS: THE WAR FOR PUBLIC OPINION 336-58 (2014).

${ }^{173} I d$. at $490-91$. Nearly all of the other New York papers declined to publish the purported order without further confirmation. Id.

174 NEELY, supra note 90, at 140.

175 Id. at 104-05.

176 Stone, supra note 2, at 14.

177 Id. at 14. 
to be from a soldier, denouncing the war effort, General Burnside ordered the paper closed. ${ }^{178} \mathrm{He}$ ignored a temporary restraining order from a federal judge, justifying his action on the ground that speech that is appropriate in peacetime becomes "rank treason" when it weakens confidence in the government. ${ }^{79}$ The newspaper closure sparked criticism by the press and public anger, with a crowd of twenty thousand gathering to protest the action, and an official denunciation from the Illinois legislature. ${ }^{180}$ Lincoln promptly allowed the newspaper to reopen, ${ }^{181}$ but newspaper closures continued. ${ }^{182}$

These actions were very likely unconstitutional even under the constitutional understandings of the time. True, it was not until fifty years later that the Supreme Court held that prior restraints are unconstitutional except in extreme circumstances, such as to prevent publishing the sailing dates of troop shipments. ${ }^{183}$ But the rule against prior restraints actually went back at least to Blackstone. Even Lincoln's own Secretary of the Navy said shutting down the World was "hasty, rash, inconsiderate, and wrong, and cannot be defended." 184

Lincoln's limited ability to control subordinates also resulted in a number of invasions of civil liberties. The problem was not a lack of formal control but political obstacles to choosing appointees or discharging them. As the discussion of the Vallandigham and Chicago Times incidents earlier showed, the culprit in both cases was an incompetent general whom Lincoln could not afford to discharge. Due to the lack of White House staff, Lincoln also had limited ability to supervise actions by less visible subordinates. At least in the case of the Lincoln Presidency, a more effectively centralized Executive Branch might have produced fewer infringements on civil liberties by keeping generals like General Burnside under control. But of course, a centralized Executive Branch in other circumstances might amplify the threat of concerted suppression of dissent.

In the time between Lincoln and Bush, the First Amendment became the basis for a powerful set of doctrines protecting speech. As we will see,

\footnotetext{
178 Id. at $14-15$.

$179 \mathrm{Id}$. at 15 .

${ }^{180} \mathrm{Id}$. at $15-16$. Holzer refers to the reaction as a "firestorm of protest." HOLZER, supra note 172, at 425 .

181 HOLZER, supra note 172, at 426. Secretary of War Stanton directed General Burnside to rescind the closure, and then followed up with a temporizing message, which arrived only after General Burnside had allowed the paper to reopen. STAHR, supra note 23, at 277-78.

182 HOLZER, supra note 172 , at 430.

183 Near v. Minnesota ex rel. Olson, 283 U.S. 697,716 (1931).

184 NeELY, supra note 90, at 104; see also MARK E. NEELY, JR., THE UNION Divided: PARTY CONFLICT IN THE CIVIL WAR NORTH 111-17 (2002) (discussing the Democratic and Republican reaction to newspaper closures).
} 
this doctrinal development sharply limited (but did not eliminate) the threat of government suppression of speech.

\section{Free Speech and the War on Terror}

The issues in Lincoln's time have no direct parallel in the War on Terror, in which free speech was a peripheral issue. The one Supreme Court case on the subject deferred to the government on national security issues, but carefully hedged its approval of restrictions on speech. Some background on the relevant statute is necessary to understand the Court's opinion.

U.S. antiterrorism legislation makes it a crime to provide "material support" to terrorist groups. ${ }^{185}$ After the 1993 attempted bombing of the World Trade Center, Congress passed legislation targeting terrorist organizations, which was strengthened after $9 / 11 .{ }^{186}$ The statute creates an elaborate procedure for designating organizations as terrorist, and providing "material support" for those organizations is a crime. ${ }^{187}$ The Secretary of State can label an organization a "foreign terrorist organization" if it engages in terrorist activity that threatens U.S. national security. ${ }^{188}$ The organization may obtain judicial review if the designation is arbitrary and capricious or otherwise illegal. ${ }^{189}$ In general, however, the courts have deferred to the government's decision to designate an organization as terrorist. ${ }^{190}$

The statute defines material support to a terrorist organization broadly. Besides concrete assistance to terrorist activities and financial support, it includes "any property, tangible or intangible, or service," except for medicine and religious materials. ${ }^{191}$ It specifically includes "training," which is defined as "instruction or teaching designed to impart a specific skill, as

18518 U.S.C. $\$ 2339$ B (2012) ("Whoever knowingly provides material support or resources to a foreign terrorist organization, or attempts or conspires to do so, shall be fined under this title or imprisoned not more than 20 years, or both, and, if the death of any person results, shall be imprisoned for any term of years or for life."). For analysis of the statute, see generally Andrew Peterson, Addressing Tomorrow's Terrorists, 2 J. NAT'L SEC. L. \& POL'Y 297 (2008).

186 Julie B. Shapiro, The Politicization of the Designation of Foreign Terrorist Organizations: The Effect on the Separation of Powers, 6 CARDOZO PUB. L., POL'Y \& ETHICS J. 547 (2008).

187 Id. at 548 .

${ }^{188} \mathrm{Id}$. at 550 . This decision must be based on a factual record, but the factual record may be classified. $I d$.

189 Id. at 551.

${ }^{190} \mathrm{Id}$. at 561 . The lower courts have refused to consider whether an organization threatens U.S. national security because they view this as too intertwined with judgments about foreign policy. See, e.g., People's Mujahedin Org. v. U.S. Dep't of State, 182 F.3d 17, 23-25 (D.C. Cir. 1999), cert. denied, 529 U.S. 1104-05 (2000). Only the organization can challenge its designation as a terrorist group. Individuals who are charged with materially supporting an organization cannot challenge the organization's designation as terrorist. Shapiro, supra note 186, at 569-72.

19118 U.S.C. $\S 2339$ A(b)(1) (2012). 
opposed to general knowledge."192 "Expert advice or assistance" is also illegal; it is defined as "advice or assistance derived from scientific, technical or other specialized knowledge." 193

The statute's constitutionality reached the Supreme Court in Holder v. Humanitarian Law Project. ${ }^{194}$ The plaintiffs claimed that they wanted to provide support for the "humanitarian and political activities" of the organizations in question "in the form of monetary contributions, other tangible aid, legal training, and political advocacy, but that they could not do so for fear of prosecution." 195 The plaintiffs wanted to teach these groups how to use legal methods to peacefully resolve disputes, to engage in political advocacy in Turkey for its members, aid the group in its nonterrorist activities, and assist in negotiating peace agreements with local governments. ${ }^{196}$

All parties agreed that combating terrorism was a compelling governmental interest. ${ }^{197}$ The plaintiffs, however, argued that assistance to support the legitimate activities of the organizations did not further terrorist activities. Hence, banning these activities was not necessary to achieve the government's compelling interest. The Court held that this "empirical question" had been considered and resolved by Congress, which defined support broadly and removed language from the law that had originally allowed humanitarian assistance. ${ }^{198}$ Chief Justice John Roberts's decision also devoted significant space to describing the reasonableness of this congressional finding. ${ }^{199}$ The Court noted that Congress had narrowed the definition of key terms in the statute in response to lower court rulings, creating exceptions for medicine and religious materials, and did not restrict independent advocacy to the public as opposed to instruction given to group members. ${ }^{200}$

\footnotetext{
192 Id. $\S 2339 \mathrm{~A}(\mathrm{~b})(2)$.

193 Id. $\$ 2339 \mathrm{~A}(\mathrm{~b})(3)$.

194561 U.S. 1 (2010).

195 Id. at 10.

196 Id. at $14-15$.

197 Id. at 28.

198 Id. at 29.
}

199 Id. at 33-36. Chief Justice Roberts's opinion includes an entire section (V.C) describing the deference owed to the Executive Branch's determination, expressed to the Court in a State Department affidavit, that "all contributions to foreign terrorist organizations further their terrorism." Id. at 33-34. The Court's decision is careful to explain that it was deferring only on the empirical question of the fungibility of support, "in an area where information can be difficult to obtain and the impact of certain conduct difficult to assess." Id. at 34 . The Court held that in the national security arena, the Government "is not required to conclusively link all the pieces in the puzzle before we grant weight to its empirical conclusions." Id. at 35 .

200 Id. at 35-36. 
The Court applied two principles - strong deference to the government and the equivalence of a group's peaceful and violent activities - that would have disturbing consequences if they applied generally in First Amendment cases. ${ }^{201}$ In dissent, Justice Stephen Breyer expressed great (and justifiable) concern about the dangers of those two principles. ${ }^{202}$ Chief Justice Roberts replied to these concerns by limiting the scope of the opinion. He indicated that "any future applications of the material-support statute to speech or advocacy" might or might not be constitutional. ${ }^{203}$ Also, "we in no way suggest that a regulation of independent speech would pass constitutional muster, even if the Government were to show that such speech benefits foreign terrorist organizations." 204 "We also do not suggest," he added, "that Congress could extend the same prohibition on material support at issue here to domestic organizations." 205 Instead, he said, "We simply hold that, in prohibiting the particular forms of support that plaintiffs seek to provide to foreign terrorist groups," the statute "does not violate the freedom of speech." 206

The carefully hedged holding in Humanitarian Law Project does not pose any general threat to free speech. But the Court's willingness to defer so heavily to the Government's assessment of national security needs is a reminder that the tension between speech and security has not been fully resolved even in our own time. ${ }^{207}$

201 See id. at 36. Providing too little deference to the authorities in cases involving national security has risks, but so does providing excessive deference, as was arguably true in Humanitarian Law Project.

202 Justice Breyer expressed skepticism of the Government's compelling interest arguments. Id. at 47-48 ("The most one can say in the Government's favor about these statements [from House Report No. 104-383] is that they might be read as offering highly general support for its argument.").

$203 \mathrm{Id}$. at 39.

204 Id.

$205 \mathrm{Id}$.

206 Id.

207 For analysis of the implications of the case, see David Cole, The First Amendment's Borders: The Place of Holder v. Humanitarian Law Project in First Amendment Doctrine, 6 HARV. L. \& POL'Y REV. 147, 149 (2012). As Professor Cole notes, the case has potentially serious implications:

For the first time in its history, the Court upheld the criminalization of speech advocating only nonviolent, lawful ends on the ground that such speech might unintentionally assist a third party in criminal wrongdoing. ... The Court treated a viewpoint-based motive for suppressing speech not as grounds for invalidation, but as a justification for the law. And the Court reduced the right of association to an empty formalism, allowing the government to prohibit, under the rubric of "material support," virtually any concrete manifestation of association-such as paying dues, donating funds, volunteering one's time or services, or working together toward common ends, no matter how lawful.

Id. at 149. While Professor Cole argues for overruling the case, he suggests that in the meantime its application be limited to "when the government is prohibiting only speech coordinated with or directed to foreign organizations that have been subjected to diplomatic sanctions for compelling national security reasons." Id. at 176. 


\section{CONCLUSION}

Like many forays into history, this Essay has shown that some things have changed and some things have not, in both predictable and surprising ways. Among the things that have changed are the size and scope of the federal government, the institutional capacity of the White House, and the types of crises facing the country. Another change is that the First Amendment is now a potent (though not unlimited) restraint on censorship, whereas it was generally irrelevant in the Civil War era except as a talking point. But some things have not changed, such as the role of politics in shaping presidential conduct and the role of the press. More surprisingly perhaps, one factor that remains unchanged is the way domestic law and international law can interact in defining presidential power. Both in the $1860 \mathrm{~s}$ and the $2000 \mathrm{~s}$, potential and actual litigation played a significant role. But in the 1860 s it was primarily the threat of civil damages that mattered, whereas in the 2000s it was judicial review of Administration actions.

Given that tensions between presidential power and the rule of law are a persistent theme in American history, we need a better understanding of how law and other institutions shaped presidential actions during crises. Although the Civil War placed the rule of law under severe pressure, Lincoln by no means operated in a law-free zone. Law can both empower and restrain. The Civil War experience indicates that presidents may turn to law as a source of legitimacy regarding even the most dramatic actions, as Lincoln did with the Emancipation Proclamation. Yet seeking legal legitimization also requires concessions to the limits created by law-again illustrated by the Proclamation, which applied only to the Confederacy, where it could be justified under the war power. We also need to better understand how political actors, the media, and public opinion can provide support for legal norms, lest we place all of our trust in presidential selfrestraint and good judgment.

The history of the Civil War is now over 150 years in the rear-view mirror. Yet it remains relevant in many ways. Among the legacies regarding presidential power was a firm determination that a President can respond to armed attack without congressional authorization, an example for better or worse of presidentially authorized detention and military trial, and a dramatic example of the dangers to free speech in time of crisis. Even today, we are far from resolving the tension between the need for presidential initiative in times of crisis and the need to confine the President within the rule of law. The Civil War generation struggled with this problem, as we have seen. If they were not always successful in their efforts to address this tension, at least they did much to illuminate the nature of the problem. 